Roman Witold Ingarden, Leon Chwistek

\title{
Polemika Romana Witolda Ingardena z Leonem Chwistkiem (teksty źródłowe)
}

\author{
Romana Witolda Ingardena recenzja \\ z Wielości rzeczywistości Leona Chwistka \\ Nowa Sztuka, 1, 1 (1921): 30-31
}

Leon Chwistek, Wielość rzeczywistości, Kraków 1921. Z zasiłkiem ministerstwa W. R. i O.P.

Książki znakomitego logika (i malarza) nie można przyjąć inaczej, jak ze słowami najżywszego uznania. W dziedzinie ścisłej myśli filozoficznej jest to bodaj pierwsza poważna próba wyjścia poza Bergsonowski intuicjonizm, niezadawalająca się jedynie li krytyką tego kierunku, lecz budująca przy pomocy metody konstrukcyjnej niebywale śmiałą i oryginalną hipotezę wielu niezależnych od siebie, równorzędnie istniejących rzeczywistości. W dziedzinie sztuki autor stwarza teorię zasadniczych typów sztuki, za pomocą której, jak powiada, „będziemy mogli usprawiedliwić wszystkie wielkie szkoły od początku świata do chwili obecnej". Dopiero teoria Chwistka daje podstawę właściwym badaniom metodologicznym, usuwając w nich ten zamęt, który wnosił bezład pojęć niezgrupowanych dokoła jednej płaszczyzny pojęciowej. Mimo pewnych zastrzeżeń, które powstają np. w stosunku do formułowania przezeń poezji, jako sztuki o walorach ściśle fonetycznych, nie można się oprzeć zdumieniu na widok tej schematyzacji i uproszczenia, które wnosi jego teoria. Dzieło Chwistka stoi, bez wątpienia, na równi z najpoważniejszymi i podobnymi dziełami na Zachodzie i nie wiadomo, ja- 
kiej już ospałości kultury polskiej należy przypisać to, że poruszywszy w sposób niezmiernie rewolucyjny ogromną ilość problematów z najprzeróżniejszych dziedzin, nie wywołało ożywionej dyskusji ze strony fachowców - filozofów, logików, psychologów i artystów. Wprowadzenie czytelnika w świat wielu rzeczywistości, z których każda rządzona jest autokratycznie własnymi swoimi prawami, filozoficzna podróż po tych rzeczywistościach, przenoszenie się z jednej do drugiej i załamywanie się ich, w interpretacji autora, składa się na ogromnie świeży, doskonale przekonywający światopogląd. Wreszcie Chwistek wyznacza miejsce sztuce dotychczasowej i buduje szkielet sztuki nowej, jako najpełniejszego wyrazu twórczego - sztuki uniezależniającej się od wrażeń zmysłowych.

Przede wszystkim autor oddaje się pracy ustalenia pojęcia rzeczywistości jako jedynej podstawy, na której może być zbudowany jakikolwiek systemat filozoficzny. Stwierdziwszy, że pojęcie rzeczywistości jest zbyt rozciągłe, by je można było zamknąć w jakimkolwiek z dotychczasowych określeń, w czym zgadza się z podobnymi wywodami Hegla, Nietzschego lub Bergsona, dochodzi do wniosku, że „nie można myśleć o zbudowania jednolitego systemu rzeczywistości, opartego na zasadach logiki formalnej, który by zadowolił wszystkie postulaty życia", i że „dogmatyczna wiara w jedną jedyną rzeczywistość prowadzi do paradoksów i nie może być przyjętą przez wszystkich ludzi". Nie znaczy to, mówi następnie Chwistek, by rzeczywistość była czymś absolutnie płynnym i niepoddającym się określeniom, jak tego chcieli wzmiankowani filozofowie, ale że istnieją zasadnicze niezależne od siebie rzeczywistości, będące jak gdyby rozmaitymi cechami materii, podobnie jak jedna i ta sama linia prosta posiada rozmaite własności w różnych systemach geometrii (Euklidesowym, Łobaczewskiego itd.). Ukazawszy, że tą jedynie droga, drogą budowy teorii wielu rzeczywistości da się rozwiązać cały szereg nierozwiązalnych problematów starej filozofii, Chwistek wyznacza I rzeczywistość rzeczy, II rzeczywistość fizykalna, III rzeczywistość wrażeń, wreszcie IV rzeczywistość wyobrażeń. Wiara w każdą z nich jest zakończonym światopoglądem, i jedynie w granicach ich możemy się poruszać.

Po ściśle filozoficznym zademonstrowaniu teorii wielu rzeczywistości autor $\mathrm{w}$ dwóch niezmiernie interesujących, ze wspaniałą tężyzną napisanych rozdziałach oddaje się pracy zastosowania swej teorii w życiu i w sztuce. W pierwszym wypadku, stwierdziwszy, że teoria ta nie tylko nie wnosi, jak by się to wydawało, zamieszania do etyki, ale na odwrót, uniezależnia ją od dowolności, których się dopuszczano przy budowie jej systemów - za jedyne kryterium moralności uważa niewykraczanie poza granice rzeczywistości, w której dany osobnik się obraca. W rozdziale: „Wielość rzeczywistości w sztuce” autor wyznacza cztery zasadnicze typy malarstwa i rzeźby, ściśle uzależnione od czterech 
rzeczywistości (p. wyżej). Jest to 1) prymitywizm, 2) realizm 3) impresjonizm, 4) tzw. sztuka nowa. Po szeregu rozważań, w których autor dowodzi, że żadnego z tych typów nie można traktować jako następczego ogniwa w szeregu rozwojowym i że kryteria ewolucjonizmu nie dadzą się do nich zastosować, autor zatrzymuje się nad sztuką modernistyczną którą uzależnia od rzeczywistości wyobrażeń i twierdzi, że kroczy ona drogą przezwyciężania treści przez formę.

Dzieło swe kończy Chwistek słowami:

„Teoria wielu rzeczywistości pozwala usprawiedliwić wszystkie zasadnicze kierunki sztuki, wyznaczając osobliwe miejsce sztuce najmłodszej. Ponieważ nowa sztuka zatacza coraz szersze kręgi, uważałem za rzecz ważną wskazać, że nie tylko nie przeczy ona pod żadnym względem wynikom badań ścisłych, ale jest poniekąd ich potwierdzeniem, dostarczając im zarazem interesującego materiału doświadczalnego". Wielość rzeczywistości prędzej czy później zajmie należne jej miejsce w rzędzie najpoważniejszych współczesnych dzieł filozoficznych. Jakkolwiek bądź, winna się ona stać podręczną książką nowoczesnego myśliciela i artysty - szczególnie tutaj, w Polsce, gdzie jest bodaj jedną jedyną książką mogącą dać czytelnikowi doskonałe uzasadnienie i wyjaśnienie istoty sztuki modernistycznej.

\section{Recenzja Romana Witolda Ingardena z Wielości rzeczywistości Leona Chwistka, Przegląd Filozoficzny 25, 3 (1922): 451-468}

\section{Leon Chwistek, Wielość rzeczywistości, Kraków 1921, stron 96}

Rozprawa stawia sobie za zadanie ustalenie znaczenia wyrazu „rzeczywistość”. Ma się to dokonać przez określenie zakresu pojęcia rzeczywistości, uzyskanego „metodą konstruktywną” a mającego zastąpić nie tylko $\mathrm{w}$ „systemie naukowym”, ale i w praktyce pierwotne pojęcie rzeczywistości. To ostatnie, którego treści autor nigdzie, choćby w przybliżeniu, nie podaje, ma z powodu płynności swego zakresu nie nadawać się do celów naukowych, a nawet "nie wystarcza do orientowania się w szeregu zjawisk zasadniczych". Dwie inne metody rozwiązywania tak przez autora zwanego „zagadnienia rzeczywistości”, z których jedną stosować mieli Hegel, Nietzsche, Bergson, a drugą „Husserl, Meinong itd.", odrzuca autor jako nieodpowiednie. Wynikiem zaś zastosowania „metody konstrukcyjnej” jest zbudowanie nie jednego, lecz czterech różnych pojęć rzeczywistości.

Przy wyprowadzeniu ich autor wychodzi z pojęcia istnienia jako pojęcia „bez porównania [sic!] ogólniejszego”. I to z pojęcia takiego, jakie 
znajduje się w dziele Whiteheada i Russella, co zdaniem autora wystarcza. Nie jest ono jednoznacznie określone, a ta wieloznaczność pociąga za sobą wieloznaczność zawartego w nim pojęcia rzeczywistości. By tę wieloznaczność usunąć, musimy zdaniem autora zwrócić uwagę na związki, jakie zachodzą między tym pojęciem a innymi pojęciami. W razie zaś ich niezależności należy wybrać twierdzenia prawdziwe „niezależnie od sposobu, w jaki wyznaczymy ich zakres". Takie twierdzenia zestawia autor w cztery układy aksjomatów wyznaczających cztery pojęcia rzeczywistości.

Układy te są następujące: I. Rzeczywistość wrażeń: (1) Jeżeli x jest bezpośrednio, to $\mathrm{x}$ jest rzeczywiste; (2) jeżeli $\mathrm{x}$ jest widzialne, to $\mathrm{x}$ jest rzeczywiste; (3a) jeżeli a jest rzeczywiste, to $\mathrm{x}$ jest widzialne lub dane bezpośrednio; (4a) sąd "x jest widzialne” jest równoważny z sądem "x jest widzialne na jawie"; (4d) dla niektórych x sąd „x jest widzialne” nie jest równoważny sądowi „x jest widzialne w warunkach normalnych"1 ${ }^{\prime \prime}$ - II. Rzeczywistość wyobrażeń: Układ ten różni się od poprzedniego tylko tym, że miejsce (4a) zajmuje postulat (4b): „Dla niektórych x nie jest prawda, by sąd „x jest widzialne” był równoważny sądowi „x jest widzialne na jawie” $\left.{ }^{2}\right)$. III. Rzeczywistość rzeczy: W układzie tym ważne są (1), (2) i (4a) z I układu, miejsce (3a) zajmuje (3b): „Pewne przedmioty rzeczywiste nie są dane bezpośrednio". Miejsce zaś (4d) zajmuje postulat (4c) „identyfikujący zakres pojęcia widzialności i pojęcia widzialności w warunkach normalnych" ( $\left.\mathrm{wx}^{\wedge} \mathrm{wnx}\right)$. Nadto dodać należy dwa postulaty: (5a) „Część przedmiotu rzeczywistego jest rzeczywista”, i (5b) „Przedmiot, którego część jest rzeczywista, jest rzeczywisty”. IV. Rzeczywistość fizykalna: układ ten różni się od poprzedniego tylko tym, że miejsce (4c) zajmuje (4d). - Układy I, III i IV są według autora niesprzeczne, niesprzeczność układu II pozostawia autor na boku.

Lecz zdaniem autora istnieją nie tylko cztery różne pojęcia rzeczywistości, ale i cztery różne tym pojęciom odpowiadające rzeczywistości. To twierdzenie ma według autora stanowić „clou” rozprawy i jej epokową nowość. Jak je autor uzasadnia, zobaczymy później. Wszystkie te cztery rzeczywistości mają być „równouprawnione”. Co to ma znaczyć, autor nie mówi. Nie zajmuje się też wzajemnym ich stosunkiem względem siebie. Ilość rzeczywistości mnoży się jeszcze przez to, że autor odróżnia rzeczywistość, w której się znajdujemy w chwili, gdy mówimy o wielu rzeczywistościach, od tychże rzeczywistości itd. Przy tym możemy przenosić się z jednej rzeczywistości do drugiej, choć to zazwyczaj nie od naszej woli zależy. Wreszcie nie wszystkie z czterech wymienionych tak samo dawno istnieją. Rzeczywistość wrażeń powstała rzekomo

1 Postulatu tego autor nie formułuje w słowach, ograniczając się do sformułowania w symbolach: $(x) .-\left(w x \equiv W_{n} x\right)$.

${ }^{2}$ W symbolach: $(\exists x) .-\left(w x \equiv W_{j} x\right)$. 
dopiero $w$ czasach, gdy się zjawił impresjonizm w malarstwie, zaś rzeczywistość wyobrażeń ma dopiero w obecnych czasach powstawać w związku z futuryzmem [sic!]. Charakter rzeczywistości godzi się przy tym $\mathrm{u}$ autora dziwnym sposobem $\mathrm{z}$ charakterem hipotetyczności, który „bądź co bądź” ma przysługiwać rzeczywistości fizykalnej.

To byłaby sama "teoria wielości rzeczywistości”. Resztę rozprawy wypełniają uzupełnienia i najrozmaitsze konsekwencje, których tu nie możemy omawiać. Zaznaczyć tylko należy, że szczególnie na sercu leży autorowi zastosowanie $\mathrm{w}$ dziedzinie teorii sztuki. Jakkolwiek - zdaniem autora - tzw. "prawdziwej” sztuce obce jest „kopiowanie” jakiejkolwiek rzeczywistości, to jednak każdy z czterech typów malarstwa, wzgl. rzeźby, jest ściśle związany z jedną z czterech rzeczywistości: prymitywizm z rzeczywistością rzeczy, realizm z rzeczywistością fizykalną (sieci), impresjonizm z rzeczywistością wrażeń, a futuryzm z rzeczywistością wyobraźni. Żaden z tych typów - konkluduje autor - nie jest lepszy ani gorszy, lecz w zasadzie wszystkie są równouprawnione; przy tym najbardziej chodzi autorowi o równouprawnienie futuryzmu $\mathrm{z}$ innymi typami sztuki.

Rozprawa nasuwa tak wiele wątpliwości i to tak różnorodnych, że ograniczymy się tutaj tylko do niektórych, poświęcając miejsce głównie omówieniu spraw metodycznych.

Każdemu autorowi wolno bez tłumaczenia się przed czytelnikiem wybrać taką metodę, jaka mu się wydaje najodpowiedniejszą. Z chwilą jednak, gdy omawia kilka metod i wybiera jedną z nich, jest obowiązany: a) znać dobrze metody omawiane, b) wykazać, że metody, które odrzuca, są dla danego zagadnienia nieodpowiednie, wybrana zaś przezeń metoda szczególnie się do tego celu nadaje i pierwsze pod tym względem przewyższa. Autor, zdaniem naszym, nie wypełnił w zadowalający sposób punktu (b), a modus, w jaki to czyni, nasuwa poważne wątpliwości co do wypełnienia (a). Zajmę się tu tylko stanowiskiem autora wobec Bergsona i fenomenologii Husserla.

Zdaniem autora stanowisko Bergsona jest następujące: Rzeczywistość jest nieskończenie bardziej skomplikowana niż to, co możemy ujać w słowa. Każda próba opisania jej przy pomocy słów jest jej zniekształceniem i dlatego prowadzi do sprzeczności ${ }^{3}$. Zadaniem więc jest "odczuć istotę stawania się, nie zrozumieć, co zrozumieć się nie da”. „Do tego celu przydatny jest aparat pojęć płynnych, z których każde może być jedynie odczute, nie zaś zrozumiane" (str. 12). Metoda Bergsona ma polegać na operowaniu pojęciami granicznymi, a jeżeli zdarzy się

${ }^{3}$ Kilka wierszy wyżej od przytoczonego właśnie zdania twierdzi dr Chwistek, że „Bergson zaczyna od stwierdzenia sprzeczności w tym, co rzeczywiste” (str. 13). Należy zauważyć, że sprzeczność zachodząca pomiędzy przytoczonymi zdaniami popełnia p. Chwistek, a nie Bergson. 
(jak przy pojęciu spostrzeżenia czystego), że te pojęcia są puste, to to nie ma być żadną trudnością dla Bergsona, gdyż "pojęciom swoim nadaje on zupełnie inne znaczenie, niż to się robi zwyczajnie". Mają one być symbolami aktów umysłowych osobliwego rodzaju, których wykonać wprawdzie nie możemy, ale których możliwość Bergson odczuwa intuicyjnie. By dać czytelnikowi pojęcie, czym ma być owo odczuwanie intuicyjne, przytacza dr Chwistek kilka dość przypadkowo z tekstu "Matière et mémoire" wyrwanych zdań.

Co do tego zdania sprawy ze stanowiska Bergsona, należy zauważyć, że jest ono tak mętne, a przede wszystkim tak powierzchowne, że można zaiste zastosować zdanie p. Chwistka (na str. 14), że jest ono jedną z owych „nieraz bardzo naiwnych interpretacji, które wypaczyły ostatecznie cel autorów". Lepiej wcale nie zdawać sprawy z cudzego stanowiska, niż czynić to w sposób świadczący tylko o tym, że autor zapoznał się tylko ze słowami wyczytanymi w dziełach Bergsona, znaczenie zaś ich pozostało mu obce. $W$ każdym zaś razie w referacie $p$. Chwistka nie został wcale wydobyty na jaw motyw, dla którego Bergson odrzuca poznanie intelektualne przy poznaniu rzeczywistości. Motyw ten zaś należało nie tylko przytoczyć, ale i omówić krytycznie z uwagi na to, że autor posługuje się sam pewną nawet krańcowo intelektualistyczną metodą. Jeżeli zaś p. Chwistek za motyw ten uważa zdanie, iż „rzeczywistość jest nieskończenie bardziej skomplikowana niż to, co możemy ująć w słowa", to świadczyłoby to o zupełnej jego nieznajomości Bergsonowskiej teorii intelektu, abstrahując już od tego, że takim argumentem sam Bergson expressis verbis wcale się nie posługuje. Dziwnym też i bezcelowym wydaje mi się sposób, w jaki autor cytuje Bergsona: po przytoczeniu 4 czy 5 zdań Bergsona odnośnik prowadzi nas do uwagi: „Matière et mémoire, p. 203-263". Czy to ma zachęcić czytelnika do skontrolowania wierności podawanych cytatów?

Rzecz ważniejsza, jakie autor podaje argumenty przeciw stanowisku i metodzie Bergsona. Otóż: prawie żadne. Za argument bowiem chyba nie może uchodzić zdanie: „Bergson popada z łatwością w bezprzykładną pretensjonalność, która w przytoczonych zdaniach graniczy z groteskowością" (str. 13). Zdanie to jest najwyżej impertynencją pod adresem bądź co bądź jednego z najwybitniejszych ludzi współczesnej Francji, impertynencją tym jaskrawsza, im mniejsze jest zrozumienie stanowiska Bergsona $\mathrm{u}$ autora ${ }^{4}$. Za argument przeciw metodzie Bergsona nie może również uchodzić uwaga autora, że Bergsonowskie pojęcia czystego spostrzeżenia i pamięci czystej są puste, gdyż dr Chwistek sam traktuje sprawę tych pojęć w sposób przykładowy i ponieważ taki czy inny sąd o nich nie ma żadnego wpływu na słuszność metody Bergsona. Zarzut,

${ }^{4}$ Dla dokładności muszę zaznaczyć, że nie podzielam stanowiska Bergsona i poddałem je ostrej krytyce. 
iż Bergson mimo opozycji przeciw „określonym symbolom” sam ostatecznie musi się niemi posługiwać, jest - choć nieściśle sformułowany słuszny, lecz wcale nie nowy. Uwaga wreszcie, iż Bergson, posługując się takimi symbolami, "czynił to w sposób mętny i niedokładny" (str. 14), nie jest poparta żadnym dowodem, mimo iż zawarty w niej zarzut jest ciężki. Lecz i prawdziwość jej nie wystarczałaby do odrzucenia metody Bergsona.

Domyślać się tylko możemy, że autor dlatego odrzuca metodę Bergsona, że ten ma być przedstawicielem „metafizyki pojęć płynnych”, autor zaś z zasady uznaje tylko taką teorię za godną uwagi, która posługuje się ściśle określonymi pojęciami o stałym zakresie i ma postać teorii matematycznej. Otóż w związku z tym należałoby wyjaśnić, jak się ma u Bergsona sprawa owych „płynnych pojęć". Przedstawienie bowiem p. Chwistka sprawia mylne wrażenie, że Bergson nie spełnia prymitywnego warunku teoretycznego posługiwania się pojęciami. Jeżeli Bergson nie chce posługiwać się aparatem pojęciowym przy poznaniu świata rzeczywistego, to motywem nie jest tu animozja do pojęć o „stałym zakresie". Bergson nie zajmuje się w ogóle zakresem pojęć, lecz niewątpliwie uznaje, że pojęcia powinny mieć zakres stały, tzn. ten sam, ilekroć jednem pojęciem w całokształcie jednego rozumowania (wnioskowania) się posługujemy. Odrzuca zaś aparat pojęć „gotowych”, którymi rozporządzamy już $\mathrm{w}$ chwili przystępowania do filozoficznego poznania rzeczywistości, ponieważ zdaniem jego: 1) treść ich jest dostosowana do wymagań życia praktycznego, 2) pojęcia jako twory intelektualne wnoszą do rozważań cały systemat formalnych struktur (schematów działania), które zastosowane do rzeczywistości prowadzą do fałszywego pod względem formalnej budowy jej obrazu, 3) ponieważ "pojęcia”, jako sposób pośredniego, nienaocznego odnoszenia się do rzeczywistości, mogą najwyżej być rezultatem, sposobem konserwowania poznania bezpośredniego, a nie instrumentem do zapoznawania się z przedmiotami. Ponieważ, jak zaznaczono, pojęcia te zostały utworzone nie dla celów poznania bezinteresownego, więc należy je odrzucić i przystąpić na nowo do tworzenia pojęć przedmiotów rzeczywistych, pojęć, które by nie wznosiły schematów działania, nie unieruchamiały płynnej rzeczywistości. I tu przy zadaniu utworzenia nowych, filozoficznych pojęć przedmiotów rzeczywistych należy się oprzeć na „intuicji” i przy tej pracy posługiwać się jako środkiem pomocniczym pojęciami "giętkimi", zdolnymi treść swą zawsze zastosować do cech przedmiotów. Czy Bergson ma tutaj rację i czy jest konsekwentny, to inna sprawa, lecz jakżeż daleki od stanowiska Bergsona jest referat autora. By zaś zbadać odpowiedniość metody Bergsona do „zagadnienia rzeczywistości”, należało: 1) zupełnie jasno, jednoznacznie i wyczerpująco sformułować zagadnienie, o które chodzi autorowi (uwagi zawarte we „wstępie” omawianej przez nas książki takiego sformułowania nie daja, a i po dyskusji 
z Bergsonem zagadnienie jasno postawione nie jest); 2) udowodnić, że metoda intuicyjna Bergsona nie nadaje się do rozwiązania tego właśnie zagadnienia, wzgl. 3) że w ogóle do żadnych prawdziwych wyników prowadzić nie może, z powodu pewnych zasadniczych braków. Tego autor, jak z powyższego wynika, nie uczynił.

Jakżeż wygląda metoda fenomenologiczna w ujęciu dra Chwistka? Ma ona polegać na „naiwnej [sic!] analizie znaczenia wyrazów” (str. 14), wzgl. zadaniem jej ma być „poszukiwanie treści wyrazów wspólnej wszystkim ludziom" $(!)^{5}$. Autor sądzi, że "postawienie przed sobą zadania, polegającego na poszukiwaniu tej treści przy pomocy analizy, nie jest a priori niedopuszczalne" (str. 14). Jednakowoż faktyczne ubóstwo wyników osiągniętych tą drogą wskazuje na to, że metoda ta nie ma widoków powodzenia ${ }^{6}$. Przyczyną tego fakt, że pojęcia pierwotne (których treść - jak się domyślamy - ma być ową treścią wspólną wszystkim ludziom) rozwinęły się pod wpływem życia praktycznego i nie nadają się do badań naukowych. Treść ich można uzyskać tylko przy pomocy banalnych inferencji, dalej posunąć się nie można. A na dobitkę i ta banalna część zadania może nas wplątać w jednostronne zapatrywania, czego dowodem rzekoma postawa fenomenologów wobec nieeuklidesowych geometrii. Mają oni podobno uważać je za "grę słów dobrą dla rozrywki umysłowej”. „Uczniowie Husserla i Meinonga”(!) mają pozostawać w zupełnej nieświadomości rzeczy dobrze znanych każdemu sumiennemu studentowi geometrii. Jeżeli więc fenomenologia nie umie „wyjaśnić tak stosunkowo prostego i poniekąd banalnego już faktu, jak istnienie wielu geometrii" (str. 15), to jakżeż ma się nadawać do wyjaśnienia sprawy rzeczywistości, która jest „bez porównania bardziej skomplikowana"? (str. 15)

Czytelnik nieznający pism Husserla i jego uczniów musi przede wszystkim dojść do wniosku, że stan współczesnej filozofii niemieckiej jest widocznie niesłychanie niski, jeżeli ów Husserl, o którym w ostatnich kilkunastu latach dość głośno było w Niemczech, takie banalności

${ }_{5}$ Przeze mnie podkreślone. Str. 14.

${ }^{6}$ Zaznaczyć należy, że tę ujemną ocenę wyników prac fenomenologicznych spotykamy tylko na początku rozprawy w trakcie dyskusji odrzucającej tę metodę. Już bowiem na str. 47 znajdujemy pewne uznanie dla prac fenomenologów, „które” rzekomo - „dostarczyły materiału pojęciowego do zbudowania systemu realizmu naturalnego". Na str. 95 zaś mamy już: „bogaty materiał pojęciowy do badań nad systemem tego rodzaju znajdziemy w pracach Husserla i jego szkoły". Taka dwoistość sądu, niepoparta żadnym argumentem, dezorietuje czytelnika nieznającego fenomenologów, a o autorze świadczy, że nie umiał sobie wyrobić sądu zdecydowanego. Przy sposobności muszę zaznaczyć, ze jest grubym nieporozumieniem, jeżeli autor sądzi, że "materialno-aprioryczne poznanie” ma cokolwiek wspólnego z "rzeczywistością wyobrażeń". Tak bliskie sąsiedztwo z rzeczywistością futurystów podziałałoby na fenomenologów co najmniej trochę niepokojąco. 
i brednie prawi. My zaś, doprawdy, najzupełniej się nie dziwimy, że autor odrzuca metodę fenomenologiczną w swojem zrozumieniu. Zadanie bowiem szukania treści wyrazów „wspólnej wszystkim ludziom" jest tak humorystyczne, że zaiste nie mielibyśmy wiele zaufania do badaczy, którzy by się czymś podobnym zajmowali. Dziwi nas tylko, że autor tego właśnie zadania nie uważa „za a priori niedopuszczalne". Ten stan rzeczy świadczy o dwu faktach, nienazbyt pochlebnych dla autora: 1) że autor wcale lub prawie wcale nie zna dzieł Husserla i fenomenologów, a w każdym razie wcale ich nie rozumie, a 2) że nienazbyt dobrze orientuje się $w$ problematyce logiki filozoficznej i teorii poznania. Tym dziwniejszy przeto śmiały ton, odsądzający fenomenologów nawet od wiadomości posiadanych przez sumiennych studentów. Autor tak dalece się nie orientuje w sytuacji faktycznej, że nie wie, iż wcale nie ma „uczniów Husserla i Meinonga” (tak, jakby to jakaś jedna grupa być miała), a tym bardziej nie wie o antagonizmach, jakie między tymi dwoma filozofami i ich uczniami zachodzą. Ponadto insynuuje autor fenomenologom pewne określone stanowisko w sprawie nieeuklidesowych geometrii (które znów wcale tak banalne nie sa, jak autor sądzi!), którego nie ma w żadnem ze znanych mi dzieł fenomenologów (a znam wszystkie prace fenomenologów, z wyjątkiem kilku powojennych publikacji, które ukazały się po ogłoszeniu pracy Wielość rzeczywistości, itd. „Philosophie der Arithmetik” Husserla, pracy pisanej w duchu psychologistycznym i nienależącej do prac fenomenologicznych). Autor cytuje przy tym wprawdzie także Meinonga, lecz to tylko świadczy o braku orientacji u autora. A gdyby nawet fenomenologowie zajmowali przypisywane im stanowisko $\mathrm{w}$ tej sprawie, to autor na zbicie tego stanowiska nie przytoczył żadnego rzeczowego argumentu; gdyby wreszcie autor miał słuszność, że to rzekome stanowisko jest błędne, to $\mathrm{z}$ faktu tego nic nie wynika a propos tego, czy metoda fenomenologiczna nadaje się do badania istoty rzeczywistości, czy nie. Nie wie autor wreszcie i o tem, że od szeregu lat sprawa istoty rzeczywistości jest wśród fenomenologów bardzo aktualna i że szereg badań przedwstępnych znajduje się w: 1) „Ideen zu einer reinen Phaenomenologie” (1913), E. Husserla, 2) „Ueber den Empfindungsbegriff” (1912), H. Hofmanna, i 3) "Zur Ontologie u. Erscheinungslehre der realen Aussenwelt", H. Conrad-Martius (1916). Badania te, choć przedwstępne, naocznie pokazuja, jak trudne i skomplikowane jest zagadnienie rzeczywistości. Autor w swej pracy nie obeznał się nawet $\mathrm{z}$ alfabetem tych trudności.

Wszystko to razem każe nam stwierdzić, że sposób krytykowania zastosowany przez autora wobec cudzych prac i metod jest $\mathrm{w}$ dziele naukowym zupełnie niedopuszczalny. Pozostałe dyskusje z innymi filozofami (Nietzsche, Poincaré) stoją na niewiele wyższym poziomie i nie przynoszą nic zasadniczo ważnego w sprawie wyboru metody. 
Po tak niezadowalającym wyrugowaniu innych metod autor po prostu stwierdza, że „pozostaje jedynie «metoda konstrukcyjna», do której najpewniejszą podstawę stanowi system logiki formalnej" (str. 17). Że jednak „nie wystarcza podanie jakiejś jednej teorji rzeczywistości, ale takiej teorii rzeczywistości, która by uwzględniła wszystkie potrzeby praktyczne, łączące się z tą sprawą” (str. 17), więc „nie będziemy mogli poprzestać na stosowaniu rezultatów systemu logiki formalnej, ale będziemy zmuszeni zrewidować budowę tego systemu od fundamentów... i na wynikach tego badania oprzeć dopiero naszą konstrukcję" (str. 17). Nie rozumiemy wprawdzie zupełnie, dlaczego ,jakaś jedna teoria rzeczywistości nie wystarcza”, nie rozumiemy, jakie to są owe „wszystkie potrzeby praktyczne, łączące się z tą sprawą", ani dlaczego względy praktyczne mają odgrywać jakąkolwiek rolę przy rozstrzyganiu czysto teoretycznego pytania "co to jest rzeczywistość"; nie wiemy, dlaczego autor decyduje się na wybór takiej właśnie metody, której podstawą jest system logiki formalnej, kiedy cztery strony wcześniej stwierdza „niezaprzeczalny fakt" - (choć znów przez autora żadnym własnym argumentem nie poparty!) - „że nie można myśleć o zbudowaniu jednolitego systemu opartego na zasadach logiki formalnej" (str. 13), lecz pomijamy to wszystko, ciekawi będąc zapowiedzianej „rewizji od fundamentów” i wyjaśnienia metody stosowanej przez autora.

Niestety, czytelnika spotyka tu rozczarowanie. Autor opisuje najpierw własności „systemu formalnego" i jego stosunek do pojęć pierwotnych; nie odgranicza jednak wyraźnie tego, co od Russella pochodzi, a co jest wynikiem jego rewizji. Natomiast obok skrajnie formalistycznego postawienia sprawy prawdziwości, która ma „obowiązywać jedynie wewnątrz systemu", obok poglądu, że twierdzenia zasadnicze jedynie z tego powodu uważamy za prawdziwe, „że wyrażają one związki pomiędzy symbolami, które same przez się są pozbawione sensu i uzyskują go właściwie(!) dopiero dzięki temu, że figurują w tych twierdzeniach" (str. 21) - znajduje czytelnik niewiążący się z tem stanowiskiem i w gruncie rzeczy z niem sprzeczny pogląd autora (będący zdaje się rezultatem owej rewizji od fundamentów, a niepoparty znów żadnym argumentem), że „wprowadzenie takich właśnie, a nie innych definicyj nie może być rzeczą przypadku, ale uwarunkowane jest pojęciami pierwotnemi, które są pierwowzorami pojęć definiowanych" (str. 24-25). Zadaniem filozofii wskutek tego ma być "podać definicję takiego pojęcia, które by w praktyce (?!) zastępowało dane pojęcie pierwotne" (str. 25). Dlaczego? Co nas pojęcia pierwotne obchodzą? Wszak według dra Chwistka zawodzą one w życiu i w nauce. Co nas skłania do tego, żeby w teorii formalnej, czy innej, występowały pojęcia treścią swą podobne do pojęć pierwotnych, jeżeli prawdziwość obowiązuje tylko wewnątrz systemu? Argumentu pro autor nie podaje i podać nie może, bo konsekwencją takiego postawienia sprawy prawdziwości jest całkowita 
dowolność w konstruowaniu treści pojęć zasadniczych. Taki pragmatyzm autora pozycji jego nie ratuje, ponieważ sam opiera się na petitio principii sprzecznym z twierdzeniami przez siebie głoszonymi, a uznawanymi przez autora. Postępowanie pewne jest „praktyczne”, tzn. że doprowadza do zamierzonych celów. Warunkiem osiągnięcia celu, o ile ma być świadomie zdobyty, a nie trafem szczęśliwego wypadku, jest między innymi wykrycie warunków zawartych w danej sytuacji i dyktujących niezbędne warunki zrealizowania celu. Zakłada to konieczność poznania sytuacji i tych warunków, zakłada uznanie prawdziwości odmiennej od tej, którą autor uznaje. Kto więc - jak autor - powiada, że dla względów praktycznych konstruuje tak, a nie inaczej podstawowe twierdzenia (czy pojęcia) swej teorii, ten tym samem w zasadzie uznaje istnienie pewnego obiektywnego porządku rzeczy, uznaje możliwość ich obiektywnego poznania, obiektywnej prawdy, mimo iż często $\mathrm{w}$ konkretnym zagadnieniu mija się z prawdą. A to mijanie się z prawdą nie wynika wcale $\mathrm{z}$ niemożliwości jej zdobycia, tylko z wprowadzenia w krąg rozważań stanów rzeczy, które do pewnego konkretnego zagadnienia teoretycznego obiektywnie nie należą. Rozumiemy wprawdzie bardzo dobrze, że autor chcący badać sprawę, czym jest rzeczywistość, nie może się całkiem otwarcie zdecydować na konstruowanie pojęć oparte na zwykłem sic iubeo autora, a pozbawiwszy się sam obiektywnego poznania i prawdy obiektywnej, szuka na darmo ratunku w pragmatyzmie. Czy jednak nie lepiej byłoby w takim razie zarzucić formalistyczne i w gruncie rzeczy sceptyczne stanowisko wobec prawdziwości, czy nie należałoby w ogóle zaniechać „metody konstruktywnej”?

O metodzie tej autor niewiele nam mówi. Przypatrzmy się lepiej, jak sam postępuje.

Pojęcie rzeczywistości jest według autora wieloznaczne. Lecz niestety wieloznaczne są i inne pojęcia, które służą do „ustalenia zakresu” pojęcia rzeczywistości. Nic nie szkodzi! - sądzi autor - wybierzemy te twierdzenia, które są "prawdziwe” bez względu na sposób ustalenia zakresu pojęć pomocniczych, i twierdzenia te stworzą nam „aksjomatykę" pojęcia rzeczywistości. Przede wszystkim: co znaczy tutaj „prawdziwe"? Czyż może tu być mowa o tej prawdziwości, która obowiązuje jedynie wewnątrz systemu? O ile rozumiemy autora, to ta prawdziwość jest wyłącznie „niesprzecznością”. Jakżeż zastosować to do aksjomatu? Autor czuje to i ma w swym arsenale przygotowane drugie pojęcie prawdziwości, które, jak przytoczyliśmy wyżej, tylko dlatego przysługuje jakiemuś zdaniu, że ono wyraża „związki zawarte pomiędzy symbolami, które same przez się są pozbawione sensu, a uzyskują go właściwie dopiero dzięki temu, że figurują w tych twierdzeniach". Wyznajemy szczerze, że nie rozumiemy dobrze, o co autorowi chodzi. Jakież to są owe związki pomiędzy symbolami pozbawionymi sensu? Symbol jest to pewien fizyczny przedmiot lub, ściślej mówiąc, pewien typowy kształt 
fizycznego przedmiotu (rysunku, plamy, tonu itp.), który dzięki umowie nabrał funkcji „wyrażenia” pewnej idealnej treści (znaczenia, sensu). Do funkcji tej niepotrzebne jest jego realne istnienie (odmiennie niż przy znaku = sygnale, por. E. Husserl, Logische Untersuchungen, II, t. I, 1 rozdz. § 1-4), bo i przedstawione symbole są symbolami; potrzebny natomiast jest między innymi związek kojarzeniowy pomiędzy jego kształtem a treścią idealna którą „wyraża”, i oczywiście ta treść. „Symbol pozbawiony sensu" symbolem nie jest, choćby miał postać podobną do postaci zazwyczaj wybieranych przez nas na symbole. Nie jest więc symbolem „abracadabra” i nie jest nim nóżka owada, która przylepiła się przypadkowo do papirusu z jakimś starym greckim napisem na miejscu nieużywanego w starożytności akcentu i akcent ten na pierwszy rzut oka imituje. Mogą zachodzić wypadki, że nie znamy sensu pewnego rysunku, który z powodu podobieństwa do używanych przez nas symbolów uważamy za jeden $\mathrm{z}$ nich. $\mathrm{Z}$ tą chwila, gdy się pokaże, że nie tylko nie znamy, lecz że nie ma wcale tego sensu, którego istnienia i powiązania z danym rysunkiem początkowo domyślaliśmy się, rysunek ten jest tylko rysunkiem i jedynie dzięki „nadaniu” mu sensu może być symbolem. Autor mógłby nam powiedzieć, że istnieją symbole, które „żadnej konkretnej treści nie posiadają", a przecież są symbolami. Co to jednak znaczy? Tylko tyle, że treść ich stanowi sens „,cokolwiek”, zakres więc obejmuje wszelkie możliwe przedmioty, ewent. z wyjątkiem samego symbolu. I tu więc sens jest. Można by wreszcie mówić o formie symbolu jako takiego, tzn. o funkcji wyrażenia "jakiejś” treści przez "jakiś” rysunek czy motyw akustyczny. Tej formy symbolu jednak zrealizować nie możemy. $Z$ tą chwilą bowiem, gdy to zechcemy uczynić, przejdziemy od formy symbolu do samego symbolu, ponieważ będziemy zmuszeni wybrać pewien określony kształt rysunku (motywu akustycznego) i sprecyzować sens (choćby w najbardziej ogólny sposób, że symbol dany oznacza "cokolwiek"). Z samych form symbolów zdań konstruować się nie da. Jeżeli więc autor mówi o „symbolach pozbawionych sensu", to albo wcale o symbolach nie mówi, albo popełnia contradictio in adjecto. Jeżeli weźmiemy szereg takich "symbolów” naprawdę bez sensu, czyli szereg arabesek, i przekładamy obok siebie, to żadne inne stosunki pomiędzy niemi powstać nie mogą prócz geometrycznych, o których oczywiście możemy wiele powiedzieć, ale w jakimś innym zdaniu, napisanym pełnymi sensu symbolami. Sam zaś układ arabesek żadnym zdaniem, wzgl. twierdzeniem, nie jest; jest rysunkiem, który naturalnie ani prawdziwym, ani fałszywym być nie może, ale zarazem nie nadaje się do żadnej teorii ${ }^{7}$.

7 Całą tę sprawę dlatego bliżej omawiamy, że stanowisko autora jest pokrewne stanowisku całego szeregu filozofów w Polsce z grupy łzw. logistyków. Uważamy 
O ile staramy się wyrozumieć, o co autorowi chodzi, to przypuszczamy, że chodzi o symbole zaopatrzone sensem „cokolwiek" i pewnym „reservatum”, iż o wyborze pewnego szczególnego sensu o węższym zakresie zdecydują dalsze fazy umowy. Możliwość tego rodzaju symbolów, a raczej takiej fazy powstawania symbolu, zupełnie uznajemy. Chodzi nam tylko o sposób wypełnienia tych dalszych faz. Otóż dr Chwistek, a z nim i inni badacze z grupy logistyków, sądza, że sens pierwotny symbolu tego rodzaju („,cokolwiek”) uszczególni się, jeżeli szereg takich symbolów o różnej postaci fizycznej poustawiamy na kilka sposobów obok siebie (nazywa się to układaniem systematu aksjomatów). Sądzę, że gdyby tylko logistycy, a w szczególności dr Chwistek, postępowali ściśle tak, jak mówią o swym postępowaniu, tzn. gdyby próbowali określić sens takich symbolów wyłącznie przez kombinowanie ich z soba, a nie podkładali pod nie od razu znaczeń wziętych czy to z nauk pozytywnych, czy też z treści „pojęć pierwotnych”, to przy pierwszej próbie przekonaliby się, że postępowanie takie nigdy nie może doprowadzić do ustalenia np. systematu aksjomatów rzeczywistości, czy arytmetyki, czy logiki itp. Cóż bowiem takie poustawianie symbolów w różnych kombinacjach obok siebie może dać? Tylko i jedynie pewne przyporządkowanie lub pooddzielanie od siebie pewnych znaków, pewne przepisy lub zakazy łączenia znaków w grupy. Sens poszczególnego symbolu z początkowego "cokolwiek" przez te przepisy nie ulega zmianie, bo zestawienie takich symbolów w grupy powoduje tylko ustalenie zastrzeżenia, że np. dany symbol x należy zawsze stawiać obok innego symbolu y. Przepis ten tyczy się samego symbolu, a nie sensu przezeń reprezentowanego. Całkiem słusznie porównywa K. Ajdukiewicz ${ }^{8}$ takie symbole do figurek szachowych: reprezentują one tylko pewien system dozwolonych lub niedozwolonych ruchów, plus - czego nie mają figurki szachowe! - ów sens „,cokolwiek”. Sens takich symbolów dopiero wówczas uszczególnia się z początkowego "cokolwiek”, gdy do połączenia ich z sobą użyjemy pełnych sensu i jednoznacznych terminów kategorialno-logicznych, np. ,jest” "i, , „albo"; wówczas np. sens symbolu, powiązanego z drugim za pomocą terminu ,"jest", o tyle uszczególnia się, że treścią jego nie jest już najogólniejsze "cokolwiek", lecz jest takie „cokolwiek", które może czy musi być cechą jakiegoś innego "cokolwiek”. Sens może się tylko z sensu zrodzić, a sensy z sobą skombinowane wzajem się modyfikuja, kombinacje arabesków mogą dać tylko arabeski. Ale i po wprowadzeniu terminów kategorialno-logicznych, które dzięki swej treści uszczególniają sens symbolów, które wiąża, pozostajemy w sferze

za rzecz niezbędną raz tę sprawę dokładnie przedyskutować w nadziei, że to choć w części przyczyni się do usunięcia nieporozumień.

8 Por. Kazimierz Ajdukiewicz, Z metodologii nauk (Lwów: Wydawnictwo Polskiego Towarzystwa Filozoficznego we Lwowie, 1921). 
najogólniejszych stosunków pomiędzy rozmaitego typu "cokolwiek”. Jakżeż daleka stąd droga do układu aksjomatów jakiejś poszczególnej dziedziny - i czy, by dojść do takiego układu, wolno stosować tę samą metodę postępowania?

Lecz wpierw jeszcze słów kilka o poruszanej wyżej „prawdziwości” takich aksjomatów, w których skład wchodzą symbole o sensie „cokolwiek", a połączone są tylko terminami kategorialno-logicznymi. Aksjomatom takim ma przysługiwać prawdziwość, ponieważ „wyrażają one związki, zawarte pomiędzy symbolami itd.". Otóż przede wszystkim żadne zdanie nie wyraża związków pomiędzy symbolami będącymi jego własnymi elementami. Zdaje się, że autor uznający teorię typów Russella nie powinien takiego błędu popełniać. Zdania wyrażają związki pomiędzy przedmiotami przynależnymi do sensów użytych w zdaniach symbolów. Po wtóre: czyż zdanie przez to samo, że wyraża takie związki między przedmiotami, staje się „prawdziwe”? A jeżeli zdanie imputuje przedmiotom domniemanym przez poszczególne symbole takie związki, które pomiędzy niemi wcale nie nachodzą? I co właściwie mamy przez „prawdziwość” zdania tutaj rozumieć? Wszak nie tę prawdziwość, która obowiązuje tylko wewnątrz systemu. Więc chyba przez „prawdziwość” rozumie autor jedynie tę cechę zdania, że wyraża ono pewne postulowane przez treść swą związki pomiędzy przedmiotami oznaczonymi danymi symbolami i to bez względu na to, czy takie związki „naprawdę" zachodza, czy nie. Nie poucza nas o tem autor, a wszak wobec oryginalności używania w ten sposób terminu „prawdziwy" powinien to był uczynić. Czy jednak przy ustawianiu aksjomatów pojęcia rzeczywistości może chodzić autorowi o taką prawdziwość, czy - innymi słowy - jego teoria o jego postępowaniu zgodna jest z nim samem? Przecież jakkolwiek powiążemy termin "rzeczywisty” $\mathrm{z}$ terminami „bezpośrednio dany”, „widzialny” itd. (np. aksjomat 1: „Jeżeli $x$ jest dane bezpośrednio, to $x$ jest rzeczywiste" ${ }^{\prime \prime}$ ), to zawsze zdania te będą wyrażały jakiś związek pomiędzy przedmiotami domniemanymi przez terminy; w myśl więc dopiero co wyłuszczonego znaczenia "prawdziwości” zawsze będą prawdziwe. I co mówić z góry o „wieloznaczności" terminów, kiedy one w myśl stanowiska autora powinny by chyba być jeszcze wszystkie „pozbawione sensu”?! Chyba więc "prawdziwość" ta jeszcze co innego oznacza, a w miejsce symbolów „pozbawionych sensu" dostajemy od razu symbole sensem obarczone

9 Zważmy przy tym, że wszystkie terminy: 1) „x”, 2) „bezpośrednio dany”, 3) "rzeczywisty” mają w myśl wyżej przytoczonego stanowiska być „pozbawione sensu" lub w myśl naszej korektury sens każdego z nich ma być "cokolwiek”, który przez zestawienie $\mathrm{w}$ wymienionym aksjomacie uzupełnia się $\mathrm{z}$ jednej strony pewnymi przepisami operatywnymi, a nadto tym uszczególnieniem, które pochodzi z powiązania symboli terminami kategorialno-logicznymi: ,jeżeli-to", , ,jest”. 
i to sensem wielorakim. Teoria więc autora o własnym postępowaniu odbiega zupełnie od tego postępowania.

Przypuśćmy jednak, że autor (popełniając niekonsekwencję) używa tu terminu "prawdziwy" w znaczeniu zazwyczaj w nauce i w życiu codziennym używanym (tzn. twierdzenie jest "prawdziwe”, jeżeli istnieje stan rzeczy przez twierdzenie domniemany), i przypuśćmy, że symbole wcale nie są "pozbawione sensu", lecz są to wzięte z życia codziennego słowa, co do których znaczenia zdajemy sobie sprawę niejasno i w niejednaki sposób. Czy wówczas szukanie twierdzeń prawdziwych niezależnie od sposobu, w jaki wyznaczymy zakres pojęć, może nas doprowadzić do celu? A celem tym jest dla autora skonstruowanie takiego pojęcia, które zastąpiłoby $\mathrm{w}$ praktyce odpowiednie pojęcie pierwotne. W jakiej „praktyce”? - w życiu codziennym? Dla nauki jest rzeczą dość obojętną jakimi pojęciami posługujemy się w życiu codziennym. W nauce? - przy rozwiązywaniu różnych teoretycznych trudności, nasuwających się np. w teorii poznania, w metafizyce, w etyce? Ależ tu nie chodzi nam zupełnie o posiadanie pojęć, które „zastępowałyby" pojęcia pierwotne, tylko o takie pojęcia, które wyłuszczałyby istotne cechy przedmiotów, zupełnie bez względu na to, jakie by były "pojęcia pierwotne". Niekoniecznie nawet musi chodzić o konstruowanie pojęć tych samych przedmiotów, których tyczą się pojęcia pierwotne, bo niejednokrotnie może się okazać, że tym żadne istniejące przedmioty nie odpowiadają. Mogą nas więc interesować tylko przedmioty i ich istotne cechy, by skonstruować pojęcia wiernie oddające te cechy istotne. Zdawałoby się więc, że by spełnić to zadanie, musimy się naprzód zająć przedmiotami, o które chodzi, i że przede wszystkim musimy te przedmioty dobrze poznać. Zamiast tego dr Chwistek po przytoczeniu trzech pojęć za pomocą „funkcji propozycjonalnych": 1) x jest rzeczywiste, 2) x jest bezpośrednio dane, 3) x jest widzialne, proponuje wybrać takie twierdzenia, które będą prawdziwe bez względu na sposób wyznaczenia zakresu tych pojęć. Czy takie twierdzenia znajdziemy? Czy znaleźć możemy wobec faktu stwierdzonego przez autora, że każde z tych pojęć, a więc że i twierdzenia same są wieloznaczne? Jakżeż możemy zbadać, czy pewne twierdzenie jest prawdziwe ${ }^{10}$, jeżeli nie wiemy, co ono właściwie powiada? I przy tym tej wieloznaczności nie wolno nam usuwać, nie wolno przeprowadzić analizy, odwołać się do przedmiotów! Wszak w tej sytuacji nie mamy jednolitego przez twierdzenie dane, domniemanego stanu rzeczy. Jakżeż możemy wówczas zbadać, czy twierdzeniu odpowiada realiter jakiś stan rzeczy? Przy tak postawionym zadaniu skończy się próba na jednym z możliwych dwu wypadków: albo 1) weźmiemy któreś z obiegowych znaczeń symbolów wchodzących w skład danego twierdzenia, albo 2) staniemy na stanowisku, że każdy z symbolów

\footnotetext{
${ }^{10}$ W znaczeniu przez nas podanym wyżej.
} 
(z wyjątkiem terminów kategorialno-logicznych) znaczy „cokolwiek”, byleby "cokolwiek" przynależne do jednego symbolu było różne od przynależnych do innych symbolów. Drugi wypadek już omówiliśmy, w pierwszym zaś jesteśmy narażeni na całkowitą dowolność, a przy tym nie będziemy mogli skontrolować, czy twierdzenie w ten sposób interpretowane będzie prawdziwe: brak nam bowiem jedynego instrumentu do tego: bezpośredniego poznania przedmiotów, o które chodzi. Na dobitkę nie osiągniemy $\mathrm{w}$ ten sposób celu, dla którego całe to postępowanie ma służyć. Cel ten wprawdzie nie jest wskazany przez autora, lecz domyślamy się go: chodzi o takie skonstruowanie pojęć zasadniczych, żebyśmy uzyskali doskonały aparat jednoznacznych i dokładnie sprecyzowanych pojęć, tak, byśmy się nim mogli z niezawodną pewnością posługiwać przy wszelkich operacjach myślowych. Miast jednego, otrzymujemy aż cztery układy aksjomatów. Wystarczyłby nam zupełnie jeden, a dobry. Tymczasem każdy z tych układów jest wieloznaczny, wzgl. niejasny, bo pojęcia pomocnicze, określające pojęcia główne, są zupełnie niesprecyzowane i każdemu czytelnikowi wolno wybierać te znaczenia, jakie mu są w danej chwili sympatyczne. Miast pewności, porządku, jasności mamy więc całkowity chaos i trzeba rzecz zaczynać $a b$ ovo ${ }^{11}$.

Tak więc "metoda konstrukcyjna” zawodzi. I nie dziwimy się teraz, że autor nie poparł jej żadnymi argumentami. Bliższe zastanowienie się nad nią okazuje jej całkowitą nicość.

Jakże teraz postępuje autor przy dowodzeniu, że istnieją cztery rzeczywistości odpowiadające układom aksjomatów? Wszak tu clou rozprawy. Posłuchajmy: „Z naszego punktu widzenia pozazmysłowa rzeczywistość Russella jest jedną z możliwych rzeczywistości, i wcale nie o to chodzi, w jaki sposób dotrzeć do pozazmysłowej rzeczywistości, ale właśnie o to, że rzeczywistość bezpośrednio zmysłami poznawalna nie jest jedna, skoro albo mamy przed sobą wrażenia i kompleksy wrażeń, które poza spostrzeżeniem istnieć nie mogą albo też rzeczy istniejące poza spostrzeżeniem, których części w ogóle są niedostrzegalne. Dwoistość ta odnosi się do każdego konkretnego przedmiotu, np. do tej lampy, którą właśnie teraz widzę. Mówiąc, że chodzi tu o jeden przedmiot rzeczywisty, który na dwa sposoby pojmuję, rozstrzygnąłbym tym samem kwestię stosunku rzeczywistości do poznania zmysłowego, co może być dokonane $\mathrm{w}$ drodze dowolnej hipotezy. Jeżeli tego chcemy uniknać, musimy zgodzić się na to, że mamy co najmniej dwie rzeczywistości zmysłowo poznawalne (przynajmniej w części)" 1) (str. 35). A dalej - str. 36 - „Nie mamy jednak żadnego kryterium a priori, które

11 My na przykład nigdy nie moglibyśmy się zgodzić na taką interpretację terminu „bezpośrednio dany”, jaka zdaje się wynikać z kilku uwag autora. Interpretacji takiej nie moglibyśmy nawet poważnie traktować. Przy metodzie stosowanej przez autora - któż rozstrzygnie, po czyjej stronie słuszność - i autor miałby rację, i my. 
pozwoliłoby rozstrzygnąć, czy rzeczywiste są elementy wrażeniowe, na które w pewnych warunkach możemy rozłożyć spostrzeżenie rzeczy, czy też elementy te są sztucznymi produktami naszego umysłu...".

Nie chcemy i nie możemy tu rozpoczynać z autorem rzeczowej dyskusji co do tego, jak się sprawa ma $\mathrm{z}$ "elementami wrażeniowymi”, „rzeczami”, ich wzajemnym stosunkiem itd., i czy rzeczywiście niemożliwym jest wykazać, które z tych elementów „naprawdę" istnieją. By dyskusję taką postawić na naukowym poziomie, trzeba by przede wszystkim opuścić sferę ogólników i prymitywnych uwag, w której się autor porusza, i przeprowadzić daleko idące badanie wszystkich elementów wchodzących w grę - a to praca, mimo badań już przez innych filozofów przeprowadzonych, jeszcze na lata całe. Chodzi nam tylko o typ postępowania autora. Jest ono takie: ponieważ nie możemy - zdaniem autora - rozstrzygnąć, która z postaw poznawczych wobec przedmiotu zapewnia nam obiektywne poznanie, więc zakładamy, że każda z tych postaw dostarcza nam takiego poznania, i wszystko, co „nam się widzi”, uznajemy za "rzeczywiste”! Rozumowanie, wyrosłe ze skrajnej obawy, by przypadkiem nie zrobić jakiejś "dowolnej hipotezy" - obawy notabene trochę nieoczekiwanej u autora opierającego swe konstrukcje na całkiem dowolnym sic iubeo - a prowadzące do postawienia również dowolnej hipotezy, za którą na dobitkę prócz przesadnego strachu przed dowolnością innych hipotez nic nie przemawia. $Z$ tego bowiem, że pole mego widzenia raz takimi, drugi raz innymi danymi jest wypełnione, absolutnie nic nie wynika à propos „rzeczywistości” tych danych.

Przypuszczamy, że omówienie niektórych momentów strony metodycznej rozprawy dało czytelnikowi pojęcie o poziomie rozprawy i że wystarcza do stwierdzenia, że za pomocą takiej metody trudno było dojść autorowi do jakichkolwiek poważnych wyników.

Jeszcze tylko jedna drobna uwaga spowodowana pewnym zdaniem z recenzji prof. T. Kotarbińskiego, na którą zresztą się najzupełniej godzimy. Prof. Kotarbiński stwierdza, że cenną i interesującą częścią rozprawy jest zastosowanie głównej tezy Wielości rzeczywistości do teorii sztuki. I niewątpliwie samo zagadnienie wyróżnienia zasadniczych typów (stylów) dzieł sztuki i zastanowienia się nad tym, czy każdemu z nich odpowiada jakaś szczególna dziedzina rzeczywistości, względnie jakiś szczególny obraz świata związany z taką czy inną postawą poznawczą podmiotu - samo to zagadnienie jest bardzo ciekawe i dla historii i teorii sztuki bardzo ważne. Lecz znów aparat metodyczny, za pomocą którego autor stara się je rozwiązać, jest wysoce niezadowalający. Abstrahujemy już od tego, że należałoby do tego celu mieć wyjaśnione naprawdę zasadnicze przynajmniej zagadnienie "teorii rzeczywistości”, czego nam książka dra Chwistka, niestety, nie daje. Lecz przede wszystkim trzeba by się postarać o bogaty materiał z zakresu historii sztuki, przeprowadzić rozległe porównawcze studia i na tak zebranym naocznym materiale, 
który należałoby czytelnikom w reprodukcjach przedstawić, trzeba by pokazać, że pewne style posiadają szczególne cechy charakterystyczne, mające swe odpowiedniki w takiej czy innej rzeczywistości. Wywody autora pozbawione tego wszystkiego tracą co najmniej swą siłę przekonywającą i rzeczowo udowodnione nie są. Że sprawa nie jest tak łatwa, jak to autor zdaje się sądzi, pouczyła mnie o tym niegdyś książka prof. Wölflina pt. Kunstgeschichtliche Grundbegriffe, na którą pozwalam sobie autorowi zwrócić uwagę. Książka ta liczy kilkaset stron, zaopatrzona jest w liczne reprodukcje, a stawia sobie za zadanie ustalić tylko kilka punktów różnicy pomiędzy dwoma stylami. Mam wrażenie, że gdyby autor był wszedł na drogę takich historyczno-porównawczych studiów, nie twierdziłby może, że realistyczne dzieła sztuki odtwarzają „,rzeczywistość fizykalną".

Dr Roman Ingarden

\section{Leon Chwistek, „Krótka rozprawa z panem Romanem Ingardenem, doktorem uniwersytetu fryburskiego", Przegląd Filozoficzny 25, 4 (1922): 541-544}

Leon Chwistek, Krótka rozprawa z panem Romanem Ingardenem, doktorem uniwersytetu fryburskiego

W poprzednim numerze Przegladu Filozoficznego wystąpił dr Roman Ingarden z „recenzją” mojej książki pt. Wielość rzeczywistości. „Recenzja” ta, utrzymana $\mathrm{w}$ tonie szkolnego patosu $\mathrm{z}$ nieodłącznym pluralis maiestaticus, jest widocznie zamierzona jako sprawiedliwe skarcenie nieświadomego rzeczy tubylca przez uczonego zagranicznej miary, wtajemniczonego w najdrobniejsze detale ruchu filozoficznego w Niemczech i gdzie indziej. W myśl tej zasady autor daleki od wysiłku wniknięcia w treść mojej książki stwierdza po prostu, że ja nie rozumiem lub nie znam omawianych autorów (Bergson, Husserl, Nietzsche, Poincaré), nie znam ważnych(?) rezultatów uzyskanych przez husserlistów w zakresie teorii rzeczywistości, nie orientuję się w problematyce logiki filozoficznej(?) i teorii poznania, poza tym zaś argumentuję w sposób prymitywny, niezasługujący na uwzględnienie.

Mam przekonanie, że bezstronny czytelnik przyjmie „recenzję" dra Romana Ingardena z poważną rezerwą i nie zechce na jej podstawie wyrabiać sobie zdania o mojej książce. Czytelnik poinformowany o tym, że dr Roman Ingarden jest pilnym uczniem prof. Husserla i jako taki wziął 
sobie za zadanie propagowanie w Polsce mętnej doktryny mistrza, nie będzie się dziwił jego i świętemu oburzeniu (Entrüstung!) na książkę, zawierającą poważne zastrzeżenia przeciw dogmatycznym uroszczeniom husserlianizmu. Nie o sąd o mojej książce chodzi więc, ale o podstawę do dyskusji, którą uważam za rzecz najważniejszą.

O czymże jednak mam dyskutować z p. Ingardenem? Czy może o tym, że w teorii Bergsona pojęcia nie mają zakresu płynnego, ale za to treść giętką(!)?

Czy mam mu tłumaczyć, jak to pierwotne na obrazie geometrycznym oparte pojęcie ułamka lub liczby rzeczywistej zastępuje się w arytmetyce teoretycznej konstrukcjami, które w pierwszej chwili wydają się sztuczne, a może nawet sprzeczne z pojęciem pierwotnym, ale niemniej w praktyce zupełnie je zastępują?

Czy mam prosić p. Ingardena, żeby uchylił rąbek tajemnicy i powiedział nareszcie, na czym polegają owe nadzwyczajne odkrycia husserlistów? Studium dra Ingardena pt. Dążenia fenomenologów, które wydawało mi się doskonałym źródłem informacyjnym, nie daje na to pytanie odpowiedzi. Pozostała literatura tego przedmiotu jest również dyskretna.

Cóż tedy pozostaje? Może najlepiej będzie ograniczyć dyskusję do konkretnego przykładu.

Zwróćmy uwagę na definicję(!) bezpośredniego doświadczenia, powtórzoną $\mathrm{w}$ wymienionym artykule informacyjnym $\mathrm{p}$. Ingardena. Okazuje się, że husserliści „rozumieją przez bezpośrednie doświadczenie każdy taki akt poznawczy, w którym przedmiot występuje sam we własnej osobie, czyli - jak mówi Husserl - jest cieleśnie samo obecny (leibhafte Selbstgegebenheit)". Jest jasne, że mamy tu do czynienia z językiem nastrojowo literackim i to bardzo niedołężnym. Nie wiadomo nawet, czy ta myśl, o którą tu chodzi, da się wysłowić po polsku. W każdym razie mamy tu do czynienia $\mathrm{z}$ określeniem, które w zastosowaniach musi prowadzić do zupełnej dowolności interpretacji. Przypuśćmy, że skupiwszy uwagę na płaskim pęku prostych przechodzących przez dany punkt oraz linię prostą znajdującą się poza tym punktem w płaszczyźnie pęku, konstatuję, że utwór ten „wystąpił sam we własnej osobie”. Przypuśćmy, że mój pęk zawiera w sobie pęk linii nieprzecinających się $z$ daną prostą. Czy mam stąd wnosić, że geometria Łobaczewskiego jest prawdziwa? Czy wobec tego pracę Beltramiego należy uważać za bezcelową? Chciałbym wiedzieć, co na to odpowie dr Roman Ingarden. Dotąd nie znalazłem podstawy do odpowiedzi na to pytanie ani w książkach husserlistów, ani w licznych rozmowach z nimi.

Pozwolę sobie skorzystać tu z uwagi prof. Wilkosza, który mówiąc ze mną o tych rzeczach, wyraził zdziwienie, że husserliści, występując w epoce tak gwałtownego rozrostu logiki i matematyki, jakiego jesteśmy świadkami, nie zechcieli chociaż na chwilę stanąć do wspólnej pracy 
w tym kierunku, jakkolwiek poruszają się nieustannie w sferze tych samych zagadnień. A przecież praca taka dostarczyłaby na każdym kroku przykładów, które porozumienie się uczyniłyby przynajmniej w części możliwym. Dopóki to się nie stanie, szanse nie są równe. Z jednej strony logicy doskonalą metodę konstrukcyjna, wierząc w jej siłę na podstawie konkretnych rezultatów matematyki, z drugiej strony husserliści opowiadają językiem nastrojowo-literackim o logice (filozoficznej?), unikając wdawania się w rozwiązywanie konkretnych zagadnień. Na domiar nieszczęścia „polski husserlista” głosi nicość metody konstrukcyjnej, zapędzając nie tylko mnie, ale wszystkich logików w kozi róg od jednego zamachu! Ten rezultat wypadł może nieco za dobrze. Jest ciekawe, że nasz filozof uzyskał go bez odwoływania się do fetyszów husserlizmu w rodzaju cielesnej samoobecności przedmiotów, ale tak po prostu, na chłopski rozum, za pomocą kilku uwag. Trudno, żebym tutaj tłumaczył p. Ingardenowi np., że Husserl, mówiąc o symbolach oznaczających symbole, miesza logikę z semantyka, i wiele, wiele innych rzeczy. Pozwolę sobie tylko zauważyć, że nasz husserlista nie łatwo spotka logika, który by twierdził, że zupełnie dobrze rozumie "pojęcie wynikania” albo geometrę, który by chciał pracować na podstawie swego „pojęcia linii prostej", niezależnie od aksjomatów Euklidesa lub jakichś innych. Wiadomo, że pojęcia te są nam do pewnego stopnia jasne, skoro możemy przy ich pomocy budować aksjomaty, ale nie na tyle jasne, żebyśmy mogli poruszać się pewnie poza systemem aksjomatów. Poza granicami takiego systemu zaczyna się dowolność interpretacji, niekończące się dyskusje, wzajemne wymyślanie sobie, słowem, to wszystko, co w nauce jest najmniej godne uwagi. W dalszej konsekwencji wyłania się autorytet (filozofia zagraniczna!), bezpłodne dociekanie tego, co też ten właśnie oficjalny filozof miał na myśli, pisząc ten właśnie frazes, i ostateczna rezygnacja z twórczości naukowej.

Ponieważ p. Ingarden udziela mi uprzejmie wskazówek bibliograficznych, pozwolę sobie zrewanżować mu się i udzielę mu rady, na jaką mnie stać. Radzę p. Ingardenowi, żeby zajął się jakiemkolwiek określonym zagadnieniem, np. tym właśnie, które postawiłem mu powyżej, i przemyślał je do końca.

Na zakończenie jestem zmuszony zwrócić uwagę na pewien bardzo smutny fakt, bo wchodzący w zakres zagadnień kurtuazji pisarskiej.

$\mathrm{Z}$ recenzji p. Ingardena dowiaduje się czytelnik, że „autor (tj. ja) decyduje się na wybór takiej właśnie metody, której podstawą jest system logiki formalnej, kiedy cztery strony wcześniej stwierdza niezaprzeczalny fakt - (choć znów przez autora żadnym własnym argumentem niepoparty!) - że nie można myśleć o zbudowaniu jednolitego systemu, opartego na zasadach logiki formalnej (str. 13) (przeze mnie podkreślone, p. 459). Czytając ten ostatni cytat, zdumiewam się, jak mogłem podobny absurd napisać. Przecież zasadnicze zadanie logiki formalnej polega właśnie 
na budowaniu jednolitych systemów. Przecież taki właśnie jest system, którego zarys ogłosiłem w poprzednim zeszycie Przegladu Filozoficznego, przecież tak właśnie pomyślany jest system realizmu naturalnego, który wypełnia V rozdział Wielości rzeczywistości.

Z niepokojem szukam wskazanej strony i oto... znajduję następujące zdanie, napisane kursywą: „,nie można myśleć o zbudowaniu jednolitego systemu rzeczywistości, opartego na zasadach logiki formalnej, który by zadowolit wszystkie postulaty życia". (Wyrazy opuszczone przez p. Ingardena są tu podkreślone). A więc tak mniej więcej, jak gdyby ktoś zdanie „nie ma ani jednego angielskiego filozofa, który by mylnie cytował”, podał w recenzji w postaci "nie ma ani jednego filozofa”. Oczywiście, zdania podanego przez p. Ingardena nie uzasadniłem ani cudzym, ani obcym argumentem, bo go nie napisałem. Twierdzenie, które napisałem na str. 13, podaję jako rezultat badań irracjonalistów, na który się godzę. $\mathrm{W}$ dalszym ciągu pracy uzasadniam to twierdzenie, po swojemu wykazując możliwość zbudowania wielu systemów rzeczywistości, z których każdy jest oczywiście jednolity i załatwia problemat rzeczywistości tak długo, dopóki znajdujemy się w pewnej swoistej dyspozycji umysłu, którą charakteryzuję jako rezultat przebywania w danej rzeczywistości. Z chwila, kiedy ta dyspozycja się zmienia, należy sięgnąć po inny system. Jeśli chodzi o tę rzeczywistość, o której mówią irracjonaliści, to oczywiście nie można zbudować jednolitego systemu, który by jej odpowiadał, bo jej po prostu nie ma, jeśli prawdziwą jest zasada, że zbiory "dane" przez pojęcia wieloznaczne są fikcjami. To wszystko starałem się $\mathrm{w}$ mojej pracy jak najsumienniej przedstawić $\mathrm{w}$ tym przekonaniu, że może dalsze badanie tego przedmiotu doprowadzi do ostatecznego wyświetlenia niezmiernie ciekawych i zawiłych zagadnień łączących się $\mathrm{z}$ tą sprawą.

Pan Ingarden powstrzymał się od wniknięcia w te rzeczy; wolał posłużyć się metodą o wiele łatwiejszą. Daleki jestem od przypisywania temu filozofowi złej woli, trudno mi jednak powstrzymać się od stwierdzenia, że nadmierna chęć doraźnego pokonania przeciwnika podyktowała mu metody niedopuszczalne w naukowej dyskusji.

\section{Roman Witold Ingarden, „Uwagi do «Krótkiej rozprawy»", Przegląd Filozoficzny 26, 1-2 (1923): 100-104}

\section{Uwagi do „Krótkiej rozprawy”}

Pozwolę sobie sprostować, wzgl. stwierdzić, następujące fakty: 
1) Czy jestem „pilnym uczniem Husserla”, jak w ogóle wszelkie ataki osobiste pod mym adresem przez p. Chwistka skierowane, nie stoją w żadnym związku ani z treścią rozprawy p. Ch., ani z treścią mego artykułu ${ }^{12}$. Atakowanie osoby w braku rzeczowej odpowiedzi na zarzuty jest metodą postępowania zapożyczoną z codziennej prasy liczącej na brak krytycyzmu u czytelników. W piśmie naukowym jest to zjawisko co najmniej dziwne. Toteż w przyszłości będę mógł odpowiadać tylko na takie "Rozprawy", które zajmują się mymi twierdzeniami, a nie osoba, i które krytykują je w sposób rzeczowy. Obecnie przechodzę do porządku dziennego nad całym tonem „Krótkiej rozprawy”, uważając go za objaw chwilowego zdenerwowania jej Autora - stanu wywołanego być może faktem, iż artykuł mój całkiem bez ogródek przedstawiał faktyczny stan rzeczy. Może byłoby się lepiej stało, gdybym był więcej „obwijał w bawełnę" mój sąd o „wielości rzeczywistości”. Wówczas p. Ch. byłby może bardziej dostępny dla mych argumentów.

2) Nie stwierdzam „po prostu”, że dr Ch. „nie rozumie, nie zna” itd., lecz wysnuwam to jako wniosek z przytoczonych przeze mnie faktów. Dr Ch. nie przytacza faktów, które by moje twierdzenia obalały. Przez powołanie się zaś na rozmowę z prof. Wilkoszem, że fenomenologowie nawet „nie zechcieli obecnie na chwilę stanąć do wspólnej pracy w tym kierunku" (matematyki i logiki - zapewne algebraicznej), dr Ch. pośrednio przyznaje rację memu twierdzeniu, iż bezpodstawnie przypisał fenomenologom pewne stanowisko $\mathrm{w}$ sprawie nieeuklidesowych geometrii.

Jeśli bowiem fenomenologowie tym się nie zajmowali, to trudno, by mieli określone w tej sprawie poglądy ${ }^{13}$.

3) Broszura p. Ch. nie zawiera „poważnych zastrzeżeń przeciw dogmatycznym uroszczeniom(!) husserlizmu", ponieważ 1) nie zawiera w ogóle jednolitego poglądu na fenomenologię (raz gani, raz chwali), 2) ganiąc zaś, wytyka - bez uzasadnienia - „ubóstwo rezultatów”, niebezpieczeństwo wpadania „w jednostronne zapatrywania”, niezdolność do wyjaśnienia tak „poniekąd banalnego(!) już faktu, jak istnienie wielu geometrii". Znać p. Ch. sam już dobrze nie pamięta treści swej broszury.

4) Nie twierdziłem wcale, że $w$,teorii Bergsona pojęcia nie mają zakresu płynnego, ale za to treść giętką". Stwierdziłem tylko brak uzasadnienia zarzutu, postawionego przez $\mathrm{p}$. Ch. Bergsonowi, a nadto przeciwstawiłem fazę operowania gotowymi pojęciami fazie tworzenia pojęć przy bezpośrednim poznawaniu ich przedmiotów. $W$ drugim wypadku

12 Por. Przeglad Filozoficzny 25, 3: 451-468.

${ }^{13}$ Dopiero w grudniu 1922 r. ukazały się w VI tomie Jahrbuch f. Philosophie 3 prace z dziedziny filozofii matematyki: F. Landau, „Ueber die Bedingungen der Möglichkeit einer deduktiven theorie”; O. Becker, „Beiträge zur phaenomenologischen Begründung der Geometrie"; H. Lipps, „Paradoxien der Mangenlehre”. 
zdaniem Bergsona muszą mieć pojęcia treść giętką gotową w każdej chwili do dostosowania się do rezultatów analizy.

5) Pojęcie ułamka i liczby rzeczywistej w arytmetyce teoretycznej i stosunek ich do pojęć pierwotnych nie stanowią analogii do konstruowanych przez dra Ch. pojęć rzeczywistości i stosunku ich do odpowiednich pojęć pierwotnych. Dr Ch. nie uwzględnia, że są przedmioty, które dają się ująć w ścisłe pojęcia graniczne (w typie pojęć matematycznych), i takie przedmioty, które na to nie pozwalają. Nie uwzględnia nadto, że istnieją nauki, których wartości nie umniejsza w niczym fakt, iż nie są odzwierciedlaniem stanów rzeczy w dziedzinie przedmiotów autonomicznie istniejących względem podmiotu poznania, a prócz nich takie nauki, którym fakt ten odebrałby wszelką wartość. Do pierwszych należą np. niektóre teorie matematyczne, do drugich np. teoria rzeczywistości.

6) Na zadane mi pytanie, co do pęku prostych i prostej, mogę tutaj odpowiedzieć, co następuje ${ }^{14}$ : różność dwu układów aksjomatów wyraża, iż przedmioty, których się tyczą są różne. Toteż fakt, iż w jednej geometrii przyjmujemy tylko jedna, $\mathrm{w}$ innych zaś więcej niż jedną prostą przechodzącą przez punkt obok prostej i równoległą do niej, tak długo nie nastręcza żadnej trudności, dopóki te same słowa (przestrzeń, prosta itd.) używane $\mathrm{w}$ dwu różnych geometriach i mających w myśl różnych systemów aksjomatów różne znaczenia nie wywołują złudzenia, iż oznaczają te same i takie same przedmioty. Czy istnieje genus proximum do przestrzeni Euklidesa i przestrzeni nieeuklidesowych, genus, który upoważniałby nas do uważania jednej i drugich za przestrzeń - jest to sprawa wymagająca osobnych i rozległych analiz. Żadnego zdania w tej sprawie nie wygłaszałem ani nie wygłaszam.

7) Dr Ch. stawia tak sprawę, jakbym ja proponował wprowadzenie na miejsce metody konstrukcyjnej metody fenomenologicznej. W artykule, przeciw któremu p. Ch. występuje, tego nie uczyniłem. Wykazywałem tylko istnienie poważnych braków metody konstrukcyjnej w wykonaniu p. Ch. i w zastosowaniu do zagadnienia rzeczywistości. Jeśli jednak chodzi o moje zdanie, to mogę tu stwierdzić (uzasadnić mógłbym na innym miejscu), że w każdym razie raczej metodą fenomenologiczną niż metodą dra Ch. można osiągnąć wartościowe rezultaty przy badaniach nad istotą rzeczywistości.

8) O symbolach oznaczających symbole nic w mym artykule nie mówiłem; cała zaś sprawa poglądu Husserla na logikę poruszona przez dra Ch. nie ma nic wspólnego z zagadnieniem rzeczywistości ani z mym artykułem. Przy tym znając trochę poglądy Husserla, ośmielam się wątpić,

${ }^{14}$ Sprawa ta wszak nie da się załatwić w kilku zdaniach, a kto tego żąda, ten chyba nie wie, jak wiele zagadnień trzeba tu rozstrzygnąć. 
czy prawdą jest, iż „Husserl, mówiąc o symbolach oznaczających symbole, miesza logikę z semantyka, i wiele, wiele innych rzeczy"(!).

9) Nie twierdziłem nigdzie, że „pojęcie linii prostej” jest na tyle jasne, „żebyśmy się mogli poruszać pewnie poza systemem aksjomatów”. Nie mam też zamiaru szukać takiego geometry, który by chciał pracować „niezależnie od aksjomatów Euklidesa lub jakich innych”. Twierdziłem tylko, że chcąc sformułować aksjomaty i układać je w system, trzeba wpierw wyjaśnić pojęcia odpowiednie, żeby były nie tylko „do pewnego stopnia", lecz całkiem jasne. Twierdziłem, że wyjaśnić pojęć podstawowych nie można bez odwołania się do bezpośredniego poznania przedmiotów tych pojęć. Bez tego ostateczne zrozumienie, jakimi przedmiotami się pewna teoria dedukcyjna zajmuje, będzie zawsze narażone na niebezpieczeństwo subiektywnych interpretacji. Zaznaczam nadto, że ustalenie aksjomatów nie jest zadaniem matematyka i nie da się metodą matematyczną rozwiązać. Matematyk z gotowych aksjomatów wysnuwa konsekwencje i musi pozostawać w obrębie aksjomatów.

10) Słuszność ma p. dr Chwistek, stwierdzając niedostateczność cytatu. Jest on rzeczywiście zniekształcony przez opuszczenie wyrazu „rzeczywistość". Zaszła tu oczywiście ubolewania godna pomyłka przy przepisywaniu tekstu, a dowiedziałem się o niej dopiero po otrzymaniu danego numeru Przegladu Filozoficznego. Gdyby Szanowna Redakcja Przegladu Filozoficznego była zechciała wypełnić mą pisemną prośbę, jeszcze w sierpniu 1922 r., o przysłanie mi korekty (przy czym w liście zaznaczałem, że chcę pewne rzeczy zmienić!), byłbym tę pomyłkę prawdopodobnie zauważył i usunął. Niestety żadnej korekty nie otrzymałem. Pan dr Chwistek nie mógł wiedzieć o tych osobliwych okolicznościach i nie dziwię się, że Go ta sprawa irytuje; aluzje jednak do „kurtuazji literackiej” itp. są co najmniej niepotrzebne ${ }^{15}$. Resztę zaś cytatu („,który by zadowolił wszystkie postulaty życia") opuściłem świadomie, bo bezpośrednio przedtem (w tym samem zdaniu), a prócz tego i w innym miejscu, mówię o tym uwzględnianiu postulatów życia; wydawało mi się więc, że nie może tu zajść nieporozumienie, że tylko o taki systemat chodzi. Niestety widać pomyliłem się, a przez to tylko osłabiłem mą argumentację. Jeżeli bowiem systemat logiki formalnej dlatego nie nadaje się do utworzenia jednolitego systemu rzeczywistości, że tak skonstruowany system nie uwzględniałby „wszystkich postulatów życia”,

15 W końcu października 1922 bawiłem w Warszawie kilka godzin w przejeździe do Lwowa i ze zdziwieniem dowiedziałem się, że artykuł mój już wydrukowano. Zwróciłem się $\mathrm{z}$ interpelacją $\mathrm{w}$ tej sprawie do p. dr. Borowskiego, prosząc, by mi Redakcja dała na kilka dni tekst do korekty. Dowiedziałem się, że to niemożliwe. Otrzymałem tylko bilet do drukarni z tym, iż p. I. „pragnie zobaczyć swój artykuł”. "Zobaczyć" oczywiście mogłem, lecz na przeprowadzenie sumiennej korekty czasu nie stało. Wolałem więc w ogóle zrezygnować z tej spóźnionej akcji. 
a z drugiej strony p. Ch. właśnie te postulaty życia pragnie uwzględnić, to niezrozumiałą jest rzeczą (a to tylko twierdziłem!), dlaczego p. Ch., zdając sobie $\mathrm{z}$ tego sprawę, pomimo to zatrzymuje metodę skrajnie intelektualistyczną, zakładającą systemat logiki formalnej. Czyżby dr Ch. sam chciał twierdzić, że jego „teoria rzeczywistości” nie daje „jednolitego systemu rzeczywistości"? Ja uważałbym to za poważny zarzut przeciw wspomnianej teorii.

11) Wreszcie muszę stwierdzić: na dwadzieścia sześć głównych zarzutów, które postawiłem rozprawie pt. Wielość rzeczywistości, p. Ch. porusza tylko te, które tu omawiam pod № 2, 4, 5, 7-10. Resztę zarzutów popartych argumentami rzeczowymi p. Ch. pomija milczeniem.

Dla uniknięcia dalszych nieporozumień podaję ex post następujące errata, które się wkradły w tekst mego artykułu:

\begin{tabular}{|cc|c|c|}
\hline & Zamiast & Powinno być \\
\hline str. 451 & w. 9 z dołu & Niezależność & Wieloznaczność \\
\hline str. 453 & w. 8 z dołu & Co & Bo \\
\hline str. 456 & w. 8 z góry & Utworzenie & Tworzenie \\
\hline str. 459 & w. 15 z góry & jednolitego systemu & $\begin{array}{c}\text { jednolitego systemu } \\
\text { rzeczywistości }\end{array}$ \\
\hline str. 460 & w. 4 z góry & Taki & Tani \\
\hline str. 461 & w. 4 z góry & Które & Która \\
\hline str. 463 & w. 2 z dołu & $\begin{array}{l}\text { zdania wyrażają związki } \\
\text { pomiędzy przedmiotami }\end{array}$ & $\begin{array}{c}\text { zdania wyrażają związki } \\
\text { pomiędzy pojęciami, } \\
\text { a omawiają związki } \\
\text { pomiędzy przedmiotami }\end{array}$ \\
\hline
\end{tabular}

Dr Roman Ingarden

Od Redakcji - „Uwagi” powyższe dr R. Ingarden nadesłał Redakcji jeszcze przed ukazaniem się zeszytu czwartego XXV rocznika Przegladu Filozof., lecz z przyczyn od Redakcji niezależnych nie mogły się one w owym zeszycie ukazać. 


\section{Romana Witolda Ingardena recenzja z Wielości rzeczywistości Leona Chwistka, Ruch Filozoficzny 7, 7-8 (1922/1923): 99-101}

\section{SPRAWOZDANIA: Leon Chwistek, Wielość rzeczywistości, Kraków 1921, wydane z zasiłkiem Min. W. R. i O. P., str. 96}

Książka ta chce ustalić aksjomatykę pojęcia rzeczywistości za pomocą tzw. metody konstrukcyjnej i kulminuje w ułożeniu czterech różnych systemów aksjomatów, jako też w twierdzeniu, że istnieją cztery różne jak autor mówi - „równouprawnione” rzeczywistości tym systemom odpowiadające. Układy aksjomatów są następujące: I. Rzeczywistość wrażeń: (1) Jeżeli x jest dane bezpośrednio, to x jest rzeczywiste; (2) Jeżeli $x$ jest widzialne, to $x$ jest rzeczywiste; $(3$ a) Jeżeli $x$ jest rzeczywiste, to $x$ jest widzialne lub dane bezpośrednio; (4a) Sąd „x jest widzialne” jest równoważny z sądem „x jest widzialne na jawie”; (4d) Dla niektórych $x$ sąd „x jest widzialne” nie jest równoważny sądowi „x jest widzialne w warunkach normalnych". II. Rzeczywistość wyobrażeń: Układ ten różni się od poprzedniego tylko tym, że zamiast (4a) występuje (4b): Dla niektórych $\mathrm{x}$ nie jest prawda, by sąd „x jest widzialne” był równoważny sądowi „x jest widzialne na jawie”. III. Rzeczywistość rzeczy: W układzie tym występują (1), (2), i (4a) z I układu; miejsce (3a) zajmuje (3b): „Pewne przedmioty rzeczywiste nie są dane bezpośrednio". Miejsce zaś (4d) zajmuje (4c) „identyfikujący zakres pojęcia widzialności i pojęcia widzialności w warunkach normalnych". Nadto dodać należy dwa postulaty: (5a) "Część przedmiotu rzeczywistego jest rzeczywista" i (5b): „Przedmiot, którego część jest rzeczywista, jest rzeczywisty”. IV. Rzeczywistość fizykalna: Układ ten różni się od poprzedniego tylko tem, że miejsce (4c) zajmuje (4d) (z I układu). Układy I, III, i IV są zdaniem Autora niesprzeczne; co do niesprzeczności układu II Autor wstrzymuje się od wydania sądu. Rozprawę uzupełniają najrozmaitsze konsekwencje między innymi w dziedzinie etyki i teorii sztuki. Autor stara się wykazać, że każdej z czterech wymienionych rzeczywistości odpowiada kolejno jeden typ dzieł sztuki, resp. kierunek artystyczny: 1) impresjonizm, 2) futuryzm, 3) prymitywizm i 4) realizm. Że zaś wszystkie cztery rzeczywistości są "równouprawnione", więc tyczy się to i wymienionych kierunków sztuki - zwłaszcza futuryzmu.

Rozprawa wykazuje rozliczne braki tak pod względem metodycznym, jak i rzeczowym. Pierwsze omawiamy szerzej na innym miejscu ${ }^{16}$, tu ograniczymy się tylko do rozpatrzenia wymienionych układów aksjomatów.

16 Por. Przeglad Filozoficzny. 
Określają one cztery pojęcia rzeczywistości, które mają zastąpić pierwotne pojęcie rzeczywistości, nieprzydatne ani dla celów naukowych, ani praktycznych z powodu swej wieloznaczności. Niestety wieloznaczne są i pojęcia proponowane przez Autora, gdyż wieloznaczne są terminy określające. Autor sam zresztą stwierdza wieloznaczność tych drugich, nie stara się jednak jej wyrugować, sądząc, że trudności uniknie przez wybranie powyższych aksjomatów, które mają być prawdziwe bez względu na sposób ustalenia zakresu terminów określających. Iluzoryczność tego mniemania wykazujemy gdzie indziej. Tu zaś pragniemy zbadać, czy Autor sam nie ulega chwiejności proponowanych przez siebie pojęć. Że Autorowi chodzi głównie o zakresy pojęć, zajmiemy się niemi. Dla krótkości oznaczamy przez:

1. Zakres pojęcia "bezpośrednio dany".

2. Zakres pojęcia „widzialny”, który rozpada się na:

2a. zakres pojęcia „,widzialny na jawie w warunkach normalnych"; 2b. zakres pojęcia „widzialny na jawie nie w warunkach normalnych";

2c. zakres pojęcia "widzialny nie na jawie".

3. Zakres pojęcia "nie dany bezpośrednio"

4a. Zakres pojęcia takich przedmiotów, których co najmniej części spełniają warunki podane w aksjomatach 1, 2, 3b, 4a, 4c.

4b. Zakres pojęcia takich przedmiotów, których co najmniej części spełniają warunki podane $\mathrm{w}$ aksjomatach 1, 2, 3b, 4a, 4d.

Wówczas zakresy proponowanych pojęć rzeczywistości przedstawiają się w następujący sposób:

1) Rz. Wr. $=1+2 a+2 b$.

2) Rz. Wyob. $=1+2 a+2 b+2 c$.

3) Rz. Rzeczy $=1+2 a+$ co najmniej część zakresu $3+4 a$.

4) Rz. Fiz. $=1+2 a+2 b+$ co najmniej część zakresu $3+4 b$.

Jak widzimy, zakresy proponowanych pojęć częściowo są sobie równe; w szczególności wszystko, co dane bezpośrednio, i wszystko, co widzialne na jawie $\mathrm{w}$ warunkach normalnych, należy do wszystkich czterech rzeczywistości, przedmioty zaś widzialne nie $\mathrm{w}$ warunkach normalnych do wszystkich rzeczywistości z wyjątkiem rzeczywistości rzeczy; wreszcie przedmioty nie dane bezpośrednio należą zarówno do Rz. Rzecz, jak i Rz. Fiz. Przez częściową różność zakresów stają się oczywiście różnymi odpowiednie pojęcia. Nie stają się jednak różnymi te same przedmioty przyporządkowane równocześnie kilku różnym zakresom, o ile oczywiście nie wskażemy w każdym wypadku na inny ich moment stający się przez przydzielenie ich do różnych grup momentem konstytucyjnym. Takiego momentu konstytucyjnego, obejmującego cały zakres definiowanego pojęcia i stanowiącego o jego jedności, u Autora brak. Bo za moment taki nie możemy przecież uważać samego wprowadzenia jednolitej nazwy obejmującej cały zakres definiowanego pojęcia. 
Wskutek tego dostajemy cztery konglomeraty, które nie wiadomo dlaczego właściwie znalazły się $\mathrm{w}$ jednym pudełku, konglomeraty niczem prócz nazwy niewiązane, a składające się po większej części z tych samych elementów. I nie może być inaczej; wszak Autor sądzi, że skonstruować pojęcie to znaczy tylko sporządzić pewien spis przedmiotów. Jaką zasadą wyboru mamy się przy tym posługiwać? Z przytoczonych systemów aksjomatów trudno ją odczytać. Być może, że Autor milcząco jakąś zasadą się posługuje; domyślać się tego pozwala nam fakt, że Autor, mówiąc o swych czterech rzeczywistościach, mówi o nich tak, jak gdyby to były cztery odrębne, wykluczające się dziedziny, przy których można się z jednej do drugiej przedostawać. Jest to wyraźne zwłaszcza przy przeciwstawieniu rzeczywistości wrażeń i rzeczywistości rzeczy i przy twierdzeniu, że rzeczywistość wrażeń powstała dopiero w okresie powstawania impresjonizmu w sztuce (!!). Dopiero też przy uznaniu takich czterech odrębnych rzeczywistości rozprawa nabiera charakteru tej sensacyjności, który Autor sam kilkakrotnie podkreśla. Ale wskazuje to tylko na to, że Autor sam w innym znaczeniu używa swych pojęć, niż mu na to pozwalają jego aksjomaty. Bo na podstawie aksjomatów można - jak wskazaliśmy - wywnioskować, że cztery rzeczywistości wcale się nie wykluczaja, lecz że przeciwnie, istnieje jedna wspólna dziedzina (złożona z zakresów $1+2 a$ ), z której można niejako robić wycieczki $\mathrm{w}$ tę czy ową stronę, dostając się do zakresów przedmiotów różnych od przedmiotów tej wspólnej dziedziny. Wskazywałoby to raczej na zupełnie inne rozgraniczenia pomiędzy „rzeczywistościami” niż te, które proponuje Autor - o ile oczywiście cechy podawane przez Autora zdolne są odgraniczyć jedną rzeczywistość od drugiej. By przeprowadzić rozgraniczenia Autora, należało wskazać albo a) na jakościowe cechy przysługujące wszystkim przedmiotom podpadającym pod jedno z pojęć rzeczywistości, a nie przysługujące przedmiotom podpadającym pod pozostałe pojęcia rzeczywistości (o ile w ogóle jakościowe różnice zdolne są konstytuować odrębne rzeczywistości!) albo b) na różnice kategorialne, albo wreszcie c) zbadać, czy charakter rzeczywistości owych czterech rzeczywistości nie jest przy przedmiotach poszczególnych pojęć odmienny, a dla nich charakterystyczny. Wówczas dopiero uzyskalibyśmy jednolitość proponowanych pojęć i moglibyśmy się przekonać, czy istotnie z czterema różnymi rzeczywistościami mamy do czynienia. Dopiero bowiem wykazanie istnienia czterech szczególnych, a między sobą różnych charakterów rzeczywistości (tego, co stanowi „rzeczywistość” przedmiotu rzeczywistego), pozwoliłoby mówić naprawdę o „wielości rzeczywistości”. Do wykrycia jednak takiego (czy takich) szczególnego charakteru rzeczywistości nie przyda się na nic ",metoda konstruktywna" i ustalanie zakresów pojęć. Charakter ów jest czymś, co my musimy znaleźć, odkryć, nie zaś konstruować, o ile oczywiście robota nasza ma mieć wartość prawdziwego poznania. Tymczasem zakresy pojęć 
możemy określać zupełnie dowolnie, bez względu na istotne pokrewieństwa między przedmiotami zaliczanymi do tego samego zakresu. Zaczynanie od określenia zakresu może być tylko pewnym sztucznym chwytem przygotowawczym do rozpoczęcia procesu poznawczego i to chwytem zupełnie niekoniecznym i często niestosownym. Przy tym przy takim postępowaniu należy zawsze zastrzec tymczasowość określonego zakresu, aż do chwili wykazania na innej drodze jego jednolitości. By odkryć szczególny charakter rzeczywistości, trzeba rozpoczać od bezpośredniego poznania, unaocznić i zrozumieć "sens" rzeczywistości, a ten "sens" dopiero określa zakres pojęcia, resp. przedmiotów pod nie podpadających. Inaczej narażamy się na fiasko analogiczne do tego, które jest wynikiem postępowania Dr. Chwistka.

Nic dziwnego też, że żaden z terminów, którymi Dr. Chwistek posługuje się do określenia zakresu pojęć rzeczywistości, nie wskazuje na ontyczny moment przedmiotów rzeczywistych. Tak „bezpośrednio dany, jak i widzialny" (w ten czy ów sposób) wskazują na pewne względne cechy przedmiotu, które mu przysługują tylko dzięki zaistnieniu pewnego stosunku poznawczego pomiędzy przedmiotem a podmiotem poznania. Cechy te mogłyby najwyżej posłużyć do ustalenia pewnych kryteriów dla sprawdzenia w konkretnym wypadku, czy przedmiot domniemany jest „naprawdę” w tym czy owym sensie „rzeczywisty”, o ile oczywiście potrafilibyśmy wykazać takie związki zachodzące pomiędzy "rzeczywistością" przedmiotu a wspomnianymi cechami względnymi, iż stwierdzenie istnienia tych drugich każe wnioskować o rzeczywistości danego przedmiotu. O ile zdajemy sobie trochę sprawę z trudności tu zachodzących, cechy wskazywane przez Autora nie wystarczają do ustalenia takich zupełnie pewnych kryteriów, zwłaszcza wobec zupełnej niejasności i wieloznaczności, która panuje u Autora co do znaczenia terminów „bezpośrednio dany” i „widzialny”. Ustalenie jednak takich kryteriów zakłada, że skądinąd wiemy, czym jest rzeczywistość przedmiotu; nigdy zaś wspomniane cechy względne nie mogą służyć do wyłuszczenia sensu rzeczywistości.

Tak więc próba Dra Chwistka zawodzi, a przyczyną tego - jak wykazujemy gdzie indziej - przede wszystkim nieodpowiednia metoda i płynący stąd brak dostatecznych wiadomości rzeczowych tak z dziedziny ontologii, jak i epistemologii. Rozprawa zbyt mało przez Autora przemyślana, a pisana w sposób, który budzi często poważne wątpliwości co do ścisłości, jasności i konsekwentności wywodów.

Dr Roman Ingarden (Toruń)*

*) Ze względu na toczącą się na łamach Przeglądu między Autorem a Recenzentem polemikę Redakcja stwierdza, iż rękopis niniejszego sprawozdania otrzymała dnia 16 sierpnia 1922. 